\title{
Different perspectives on management systems integration
}

\author{
João Almeida ${ }^{\mathrm{a}}$, Pedro Domingues ${ }^{\mathrm{b}}$ and Paulo Sampaio ${ }^{\mathrm{b} *}$ \\ ${ }^{a}$ Department of Environmental Health, College of Health Technology of Coimbra, Coimbra, \\ Portugal; ${ }^{b}$ Systems and Production Department, School of Engineering, University of Minho, \\ Braga, Portugal
}

\begin{abstract}
Increasingly competitive economies and the market globalisation process have led many organisations to implement management systems as a differential against competition. However, with the variety of standards available, they felt the need to integrate management subsystems aiming at resources and skills optimisation, in order to achieve performance maximisation of the resulting integrated management system (IMS). Added to this, it is known that the value of a single certificate is inversely proportional to the overall increase in certificate numbers. This paper intends to report the study results focusing on critical success factors (CSFs) assessment, difficulties faced by organisations when implementing an IMS, and the resulting benefits. Additionally, the quantitative evolution of IMS in Portuguese companies until 2011 is reported, showing how IMS typologies evolved and increased their relative 'weight' among Portuguese certified companies. Related to the study, the sample was composed of four Portuguese IMS ruled organisations based on quality, environment and occupational health and safety certified management subsystems. The data collection methodology was based on semistructured interviews with the management system manager, through which it was sought to analyse the entire integration process. Results suggest that management subsystems integration contributes positively to the studied organisations. Top management involvement, human and financial resources availability and training were identified as subsystems integration CSF. Among the difficulties faced by organisations they pointed out the non existence of a previous organisational structure and the employees' behaviour changes.
\end{abstract}

Keywords: management systems; integration; critical success factors

\section{Introduction}

Due to technological advancement, uncontrolled global growth and human life-increasing prospects, the industrial development concept has changed. In addition to this change, the economic globalisation process and the enlargement of competitive markets have led many organisations to extend their business segment, making it more comprehensive and differentiated from the competition (Billig \& Camilato, 2008; Ferreira, 2009).

Thus, organisations have sought to identify and develop management systems that provide an adequate cost-benefit relationship and, at the same time, a prominent position in the market in which they operate, enhancing, among others, costs and losses reduction during the production process (Domingues, Sampaio, \& Arezes, 2012; Hoyle, 2005).

Currently, there is a wide range of management systems standards. Those standards cover several functional areas within an organisation, intending, among other issues, to provide more confidence to stakeholders, both internal and external (Sampaio, Saraiva, \& Rodrigues, 2008). With separate and sometimes incompatible management subsystems,

\footnotetext{
*Corresponding author. Email: paulosampaio@dps.uminho.pt
} 
organisations incur significant costs, increase in errors and failures, efforts duplication, unnecessary bureaucracy and excessive documentation. These issues have a very significant negative impact on stakeholders, mainly employees and customers (Beckmerhagen, Berg, Karapetrovic, \& Willborn, 2003; Domingues et al., 2012; Sampaio, Saraiva, \& Domingues, 2012). According to Asif, Fisscher, Bruijn, and Pagell (2010) the strategy should be the integration of those standards in a holistic system, so that organisations could manage their operations through a single management system (Rasmussen \& Jørgensen, 2007).

A holistic management allows companies to a share human, material, informational, infrastructural and financial resources pool (Karapetrovic \& Jonker, 2003). This leads to subsystems valorisation enhancing common aspects synergies within different standards (Crowder, 2013; Renzi \& Cappelli, 2000) and improving organisational efficiency and profitability (Abrahamsson, Hansson, \& Isaksson, 2010). This type of management promotes an effective management model that can be integrated with other management requirements from the point of view of organisations' top management (Waclawovsky \& Batiz, 2010), and also a sustainability warranty (Kuei \& Lu, 2013). Despite the previous mentioned benefits, some authors state that the implementation of multiple management systems may hinder innovation (Castillo-Rojas et al., 2012).

The main objective of this research is to assess the critical success factors (CSFs) during an integrated management system (IMS) implementation. Additionally, we intend also to identify the difficulties and barriers faced by the organisations when they integrate several management subsystems, and the resulting benefits. To achieve these objectives, case studies were carried out based on semi-structured interviews with the management system manager.

\section{Literature review}

In contemporary markets, organisations are becoming increasingly concerned that their customers feel unique sensations with their products and/or services. Thus, a growing number of organisations are using the quality management system (QMS) as a strategy to increase competitiveness and improve their performance, as these ensure that products and/or services are in compliance with requirements (Gill, 2009).

The 'quality assurance' led to international efforts in order to develop a QMS that should operate as a guarantee concerning performance, methods and control procedures, materials, technical specifications and guidelines for production and inspection (Miguel \& Dias, 2009). According to Sampaio and Saraiva (2010a), management systems can be defined as a set of interrelated organisational processes which uses resources to achieve different organisational goals. Additionally, they provide the organisation with a recognised effort to assure products and/or services compliance, customer satisfaction and continuous improvement (Pojasek, 2007).

QMS implementation should be a strategic and voluntary organisational decision. The organisation can implement a QMS aiming at internal improvement and it may be interested in external recognition (certification). However, in general, most companies that implement a QMS are very certification oriented. This is due to the fact that certification is the recognition by an independent external entity that the organisation is able to meet customer requirements as well legal and regulatory requirements effectively (ISO, 2010). 
On the other hand, with the industrial revolution, the progress concept became prevalent, and all natural resources began to be seen as raw material for generating new products, resulting in natural environment degradation.

Environmental protection and pollution prevention are current concerns for any organisation. The intensification in public awareness and discussion on these matters, and the existing national and community laws applicable to environmental management, reinforce the need to implement an environment management system (EMS) (Kanji \& Chopra, 2010). Thus, it is necessary to adopt an EMS based on prevention and good practices, that promptly answer to companies external pressures and needs (Brio, Fernández, Junquera, \& Camilo, 2001), focused on natural resources optimal use, environmental protection and pollution reduction (Patrício, 2003).

Fresner and Engelhardt (2004) state that an EMS implementation allows the acquisition of a deep insight into the most important environmental aspects related to the company activity, and to identify processes that need to be improved through effective environmental measures implementation.

Occupational safety and hygiene issues also became increasingly recognised as an important factor, not only for employees but also for the organisations. Some weaknesses have been spotted in the way organisations identify, analyse and manage hazards and risks related to their activities, locations and workstations. This fact is highlighted in the conclusions resulting from industrial accidents investigations such as Seveso (1976), Three Mile Island (1979), Bhopal (1984), Piper Alpha (1986) and Chernobyl (1986) among others (Al-Darrab, Gulzar, \& Ali, 2012; Mitchison and Papadakis, 1999; Pinto, 2005). In fact, the traditional cause-effect approach is not effective due to labour relationships complexity, increasing technological intricacy and the rhythm of change that organisations face due to global market demands and pressures (Mitchison \& Papadakis, 1999; Pinto, 2005).

Assuming the occupational health and safety management system (OHSMS) as a guarantee of risks and costs reduction related to accidents repair, this management system proves to be a tool that, when properly implemented, allows the organisation to objectively obtain data about its performance concerning the occupational health and safety area, in all its aspects, allowing the implementation and adoption of decisions based on facts.

The implementation of one or more management subsystems in an organisation does not require a minimum organisational performance level or reaching a pre-defined result, but should contribute to that goal. It establishes the need to systematise and formalise a set of organisational processes related to different business areas. However, according to Sampaio and Saraiva (2010b), management systems implementation is not always effectively performed, leading to the commonly referred criticism that a management system increases the organisations bureaucratic burden, and causes a certain organisational 'stiffness' reflected in a variety of intra-organisational silos, according to each subsystem typology.

The trend towards quality is nowadays perceived from a wider angle, including environmental management and safety at work (Brio et al., 2001). This trend, leading to management systems standards growth, emphasised the need to integrate them into a holistic system (Asif et al., 2010). The idea that is supporting this concept implies that an organisation may, as far as possible, manage its operations through a single management system instead of several individual management subsystems. The IMS concept became more relevant after the ISO 14001 standards publication, but increasingly wider due to other standards release such as OHSAS 18001, ISO 22000, SA 8000, among other sector standards (Rasmussen \& Jørgensen, 2007). 
The term IMS may cover a wide range of different management subsystems. However, the most common IMS subsystems combination is the QMS, EMS and OHSMS integration one. Nevertheless, an IMS has not, necessarily, to encompass all subsystems. An organisation may choose to integrate the QMS and EMS, while another may choose to integrate the QMS and OHSMS, meaning that organisations integrate management subsystems according to their own strategy (Rasmussen \& Jørgensen, 2007).

In order to realise the importance of integrating these subsystems it is necessary to understand each, namely it scope and extension. Table 1 presents a comparative analysis between the three main management systems standards (Capelas, 2002).

Based on Figure 1, an IMS has more fulfilled requirements with fewer resources than a non-integrated system. It is important to point out that in an integration process there is a set of requirements that are possible to integrate and share among the different management subsystems, but there are also some specific requirements that do not allow integration with any other management subsystems. This is the true concept of integration - we cannot integrate everything.

There are several integration methodologies suggested. The final feature to be highlighted is the integration degree. Just like the strategy and the methodology, the decision regarding which integration degree an organisation should achieve relies on the organisation itself. According to the literature, there is not a unique model for all organisations (Bernardo, Casadesus, Karapetrovic, \& Heras, 2009). In order to reach a successful integration, it is not enough to follow a methodological path or model steps. In addition to introducing the process, the organisational background must be prepared, ensuring that it has appropriate processes, technology and human resources to face new changes and strategies (Hypolito \& Pamplona, 1999).

\section{Research methodology}

The information gathered to support this research was based on case studies. Case studies results may have a significant impact on research and may lead to new discoveries and to the development of valid and useful theories for professionals (Voss, Tsikriktsis, \& Frohlich, 2002). Meredith (1998) states that this methodology helps to understand why certain characteristics are observed in target cases.

Table 1. Major differences between standards (Capelas, 2002).

\begin{tabular}{|c|c|c|c|}
\hline & ISO 9001:2008 & ISO 14001:2004 & OHSAS 18001:2007 \\
\hline Purpose & $\begin{array}{l}\text { QMS continuous } \\
\text { improvement and } \\
\text { customer satisfaction }\end{array}$ & $\begin{array}{l}\text { Support environmental } \\
\text { protection and pollution } \\
\text { prevention }\end{array}$ & $\begin{array}{l}\text { Control risks and } \\
\text { improve } \\
\text { performance }\end{array}$ \\
\hline Focus & Customers & Society & Collaborators \\
\hline $\begin{array}{l}\text { Scope of } \\
\text { application }\end{array}$ & Products and services & $\begin{array}{l}\text { Environmental aspects } \\
\text { (includes desired and } \\
\text { undesired products and } \\
\text { services and resources } \\
\text { utilisation) }\end{array}$ & $\begin{array}{l}\text { Occupational risks to } \\
\text { safety and health of } \\
\text { collaborators }\end{array}$ \\
\hline $\begin{array}{l}\text { Scope of } \\
\text { activities } \\
\text { covered }\end{array}$ & $\begin{array}{l}\text { Internal application by } \\
\text { organisations. QMS } \\
\text { effectiveness meeting } \\
\text { customer requirements }\end{array}$ & $\begin{array}{l}\text { All processes and activities } \\
\text { of an organisation with } \\
\text { environmental aspects }\end{array}$ & $\begin{array}{l}\text { All activities } \\
\text { associated with } \\
\text { quantifiable } \\
\text { occupational risks }\end{array}$ \\
\hline
\end{tabular}




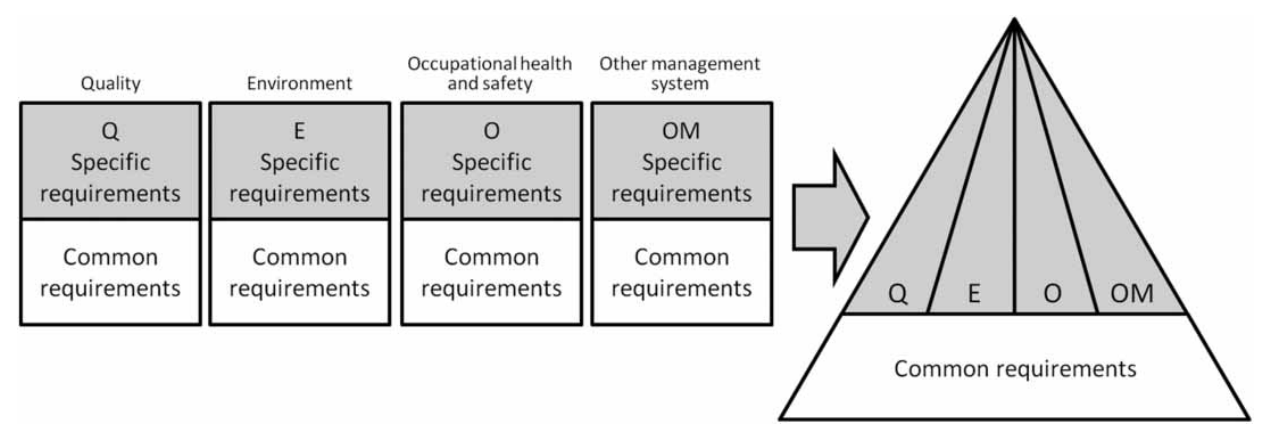

Figure 1. Management subsystems integration (Vasconcelos, Melo, \& Silva, 2010).

Case studies were based on semi-structured interviews (based on an interview protocol defined by Sampaio Saraiva, 2010a) with the IMS managers from each one of the targeted organisations, in order to understand how the IMS had been implemented, what its contribution was to the organisation and which the implementation CSF was.

Four IMS certified organisations, QMS and EMS and OHSMS based on, were the selected case studies. In this selection, the number of organisations targeted in other studies with a similar research methodology, such as Fresner and Engelhardt (2004), Grael and Oliveira (2009), Karapetrovic and Casadesús (2009), Sampaio et al. (2012) and Welikala and Sohal (2008), was taken as reference. Organisations selection was performed considering management systems with different integration levels. The choice of these organisations and their classification regarding their integration level were based on information gathered from certification bodies, auditors and consultants. To evaluate the integration level, the information and the integration levels identified in the literature were considered. Thus, for this study purpose, organisations were classified as low integration level organisations (LILO) and high integration level organisations (HILO), according to whether they implemented just a documental-based system or a higher order integrated system concerning goals and management tools alignment (Bernardo et al., 2009; Karapetrovic, 2002).

After data collection, the stages suggested by Eisenhardt (1989) and Voss et al. (2002) were adopted. Initially, the information collected was analysed and, at a later stage, it was sought to identify possible patterns in the different case studies, comparing what characterises a HILO and a LILO company.

\section{Case studies}

The four studied organisations develop their activity in the following activity sectors: mines and mining, wholesale trade and civil construction. One organisation is located at the Portuguese northern region and the remaining three are located at centre region. The organisations employees' number range between 15 and 150 .

\section{Managers' socio-biographical data}

Concerning the management system manager, it was assessed that in HILO he/she has a lower average age ( $x=31$ years), a higher educational qualification level and a lower 
service length when compared to LILO (Table 2). By performing a socio-biographical data analysis, one may conclude that, despite the small number of case studies conducted, these factors could influence in the management subsystems integration.

\section{Integration sequence}

The four organisations reported that they have started the OHSMS implementation and simultaneously integration with the EMS, based on a previous implemented QMS. Douglas and Glen (2000), who also found similar results, claim that this fact is not surprising given the high number of organisations with a certified QMS, when compared to other standards. However, two organisations (LILO) have only integrated some procedures and documentation. Concerning the integration process duration, the HILO companies decided to integrate the subsystems five years after the QMS implementation. On the other hand, in LILO companies, one of them implemented the three subsystems simultaneously, proceeding to certification in the following year and the other LILO organisation performed a documental integration based on the subsystems common documentation and it compilation in single documents.

\section{Motivation for IMS implementation}

Given the motivation that led the organisations to integrate their management subsystems, respondents considered corporate image improvement, stakeholders' relationship improvement, processes optimisation, documentation reduction and internal organisation improvement as the main motivations to management systems integration (Table 3 ). There is a noticeable difference between the two organisations groups - one may verify that the HILO group indicates motivations related to the system optimisation and efficiency improvement, and the LILO one indicates the documentation reduction as the main motivation for integration.

\section{Difficulties and barriers during the integration process}

During the management subsystems integration, organisations have faced difficulties, namely HILO companies (Table 4). These difficulties, also identified by authors such as Sampaio et al. (2008, 2012), Santos, Mendes, and Barbosa (2011) and Simon, Bernardo, Karapetrovic, and Casadesús (2012), occurred mainly at the internal restructuring level and employees' behaviour change. LILO companies did not indicate obstacles, due to the fact that they have only performed documental integration.

Table 2. System managers' socio-biographical background vs. the integration level.

\begin{tabular}{lcc}
\hline & HILO & LILO \\
\hline IMS manager qualifications & Graduation & High school \\
Average age of the IMS manager (years) & 31 & 48.5 \\
Average time of service in the organisation (years) & 6 & 18 \\
Number of companies & 2 & 2 \\
\hline
\end{tabular}


Table 3. Motivations for management systems integration.

\begin{tabular}{|c|c|c|c|c|}
\hline \multirow[b]{2}{*}{ Motivation } & \multicolumn{2}{|c|}{ HILO } & \multicolumn{2}{|c|}{ LILO } \\
\hline & A & $\mathrm{B}$ & $\mathrm{C}$ & $\mathrm{D}$ \\
\hline Marketing tool/image improvement & $\mathrm{X}$ & $\mathrm{X}$ & $\mathrm{X}$ & $\mathrm{X}$ \\
\hline Internal process optimisation & $\mathrm{X}$ & $\mathrm{X}$ & & \\
\hline Marketing differentiation & $\mathrm{X}$ & & & \\
\hline Give response to customers with specific demands & $\mathrm{X}$ & & & \\
\hline Improve effectiveness and systems control & $\mathrm{X}$ & & & \\
\hline Top management decision & & $\mathrm{X}$ & & \\
\hline Economic support for investment projects & & $\mathrm{X}$ & & \\
\hline Cost reduction associated to resources involved & & $\mathrm{X}$ & & \\
\hline Customers and suppliers relationship improvement & & & $\mathrm{X}$ & \\
\hline Internal organisation improvement & & & $\mathrm{X}$ & \\
\hline Documentation reduction & & & $\mathrm{X}$ & $\mathrm{X}$ \\
\hline
\end{tabular}

\section{Perceived integration level}

When asked about the management system integration level (Table 5), HILO companies consider that their subsystems are well and fully integrated, which is consistent with the 'all-inone' system referred by Karapetrovic (2002). In this approach at least four integration levels can be distinguished: policies, documental integration, objectives and goals definition and, finally, management tools alignment. The LILO firms state that their integration level is reduced since it only reflects a documental level while the processes remain separate, being classified as a partial integration according to Bernardo et al. (2009). The difference between HILO and LILO is evident, in the sense that the first ones refer different levels and the second ones have not been able to identify those levels, thus reflecting their low integration level. These organisations had integrated their management subsystems based on standards shared linkages (Douglas \& Glen, 2000).

\section{Benefits of management systems integration}

It was possible to verify that management subsystems integration is assumed as an important issue for the performance of the HILO organisations, namely in terms of management

Table 4. Difficulties related to the management systems integration.

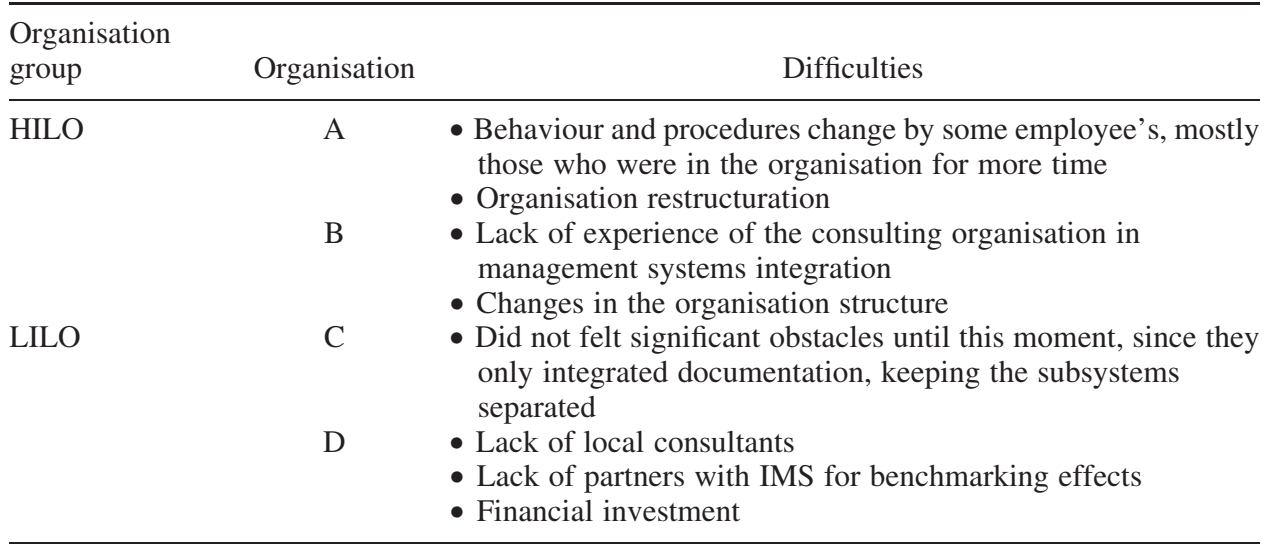


Table 5. Integration levels.

\begin{tabular}{|c|c|c|c|}
\hline $\begin{array}{l}\text { Organisation } \\
\text { group }\end{array}$ & Organisation & $\begin{array}{l}\text { Number of } \\
\text { integration levels } \\
\text { identified }\end{array}$ & Features \\
\hline \multirow[t]{2}{*}{ HILO } & A & 4 & $\begin{array}{l}\text { - Systems find themselves well integrated. } \\
\text { However, there are improvements to be } \\
\text { done } \\
\text { - Identified levels: } \\
1 \text { - Policy } \\
2 \text { - Documentation support } \\
3 \text { - Objectives and goals } \\
4 \text { - Operational control/management } \\
\text { tools }\end{array}$ \\
\hline & B & 5 & $\begin{array}{l}\text { - Even having the notion that it can be } \\
\text { improved, a maximum level integration } \\
\text { was considered. It was also considered } \\
\text { that it was still in a growing stage where } \\
\text { the integration with other management } \\
\text { subsystems will be easier } \\
\text { - Identified levels: } \\
1 \text { - Policy } \\
2 \text { - Documentation support } \\
3 \text { - Objectives and goals } \\
4 \text { - Operational control/management } \\
\text { tools }\end{array}$ \\
\hline \multirow[t]{2}{*}{ LILO } & $\mathrm{C}$ & 2 & $\begin{array}{l}\text { - Integration only at the documental level. } \\
\text { As far as operational control concern, } \\
\text { there is still an independent approach, at } \\
\text { the quality, environment and safety level } \\
\text { Identified levels: } \\
1 \text { - Documentation } \\
2 \text { - Policy and objectives }\end{array}$ \\
\hline & $\mathrm{D}$ & 1 & $\begin{array}{l}\text { - Only integrated at documental level } \\
\text { - Identified levels: } \\
1 \text { - Documental integration }\end{array}$ \\
\hline
\end{tabular}

system efficiency and improvement and in customers' specific requirements satisfaction. For the LILO companies the management systems integration has no significant impact in operational terms. In fact, their main motivations do not correspond to the internal motivations category, because they are mainly focused on marketing and promotional issues that could be achieved in the integration process.

The main benefits perceived by HILO companies were related to organisational process issues namely operational improvement due to an organisational culture change. The LILO ones pointed out benefits mainly in terms of documents reduction (Table 6), with this benefit identified in other studies such as in Douglas and Glen (2000), Brio et al. (2001) and Zeng, Xie, Tam, and Shen (2011). Brio et al. (2001) claim that sharing the documentation promotes redundancies elimination in procedures. Douglas and Glen (2000) also identified procedures improvement, costs reduction and a more flexible management as integration benefits. Zeng et al. (2011) add management costs and internal management complexity reduction, a simpler certification process and a more continuous improvement oriented company as other benefits. 
Table 6. Integration benefits.

\begin{tabular}{|c|c|c|c|c|}
\hline Benefits & & & & LILO \\
\hline Stakeholders relationship improvement & $\mathrm{X}$ & $\mathrm{X}$ & & \\
\hline Procedures organisational improvement & $\mathrm{X}$ & & & \\
\hline Behaviour changes at environmental and safety levels & $\mathrm{X}$ & & & \\
\hline Sharper responsibilities definition & $\mathrm{X}$ & & & \\
\hline Documentation reduction & $\mathrm{X}$ & & $\mathrm{X}$ & \\
\hline Indirect cost reduction & $\mathrm{X}$ & & & \\
\hline Global vision from top management & & $\mathrm{X}$ & & \\
\hline Better work and organisation & & $\mathrm{X}$ & & \\
\hline Employee's communication improvements & & $\mathrm{X}$ & & \\
\hline Effectiveness and efficiency gains & & $\mathrm{X}$ & & \\
\hline Systematisation and procedure speed increase & & & $\mathrm{X}$ & \\
\hline
\end{tabular}

Considering the resultant benefits, HILO companies stated that if the organisation had not implemented/integrated the management system, the performance level would be lower than the current one. In HILO group this process was undoubtedly a path to improved performance. Both HILO organisations considered that they achieved a superior performance level when compared to the level prior to integration. On the other hand, LILO companies acknowledge the improvement at the documentation level, but not enough to consider a higher performance level achievement. These results suggest that, in fact, only with a complete and deeper management system integration it is possible to achieve the added value and the benefits that integration allows one. Only in this case, organisations could achieve a higher performance, thus increasing the management system effectiveness and efficiency.

Regarding the ease of standards integration, the HILO companies consider that OHSAS 18001 and ISO 14001 are more suitable to integrate due to their similarity. On the other hand, the LILO group experienced some difficulties in the integration process, not because the lack of compatibility between the standards, but due to the non existence of a previous organisational structure.

\section{Critical success factors}

CSF could be defined as vital areas or agents that the organisation must take into consideration to achieve a successful integration (Salaheldin, 2009). When asked about the success factors related to management subsystems integration, organisations have identified the set of factors described in Table 7.

Based on the CSF identified by the organisations, the following are pointed out as the most important:

- Top management involvement;

- Financial resources availability;

- Employees involvement and/or motivation;

- Human resources suitability;

- Training;

- Consultants with integration experience.

In fact, top management involvement and commitment are critical to a successful management system integration (Garengo \& Biazzo, 2012). This commitment influences the 
Table 7. CSF for management systems integration.

\begin{tabular}{llllll}
\hline CSF & \multicolumn{2}{c}{ HILO } & & \multicolumn{2}{c}{ LILO } \\
\hline Top management involvement & X & X & X & X \\
Financial resources & X & & X & X \\
Human resources & X & & X & \\
Training & X & & X & \\
Well defined objectives & X & & & \\
Persistence & X & & & \\
Employees involvement and/or motivation & X & X & & \\
Consultants with integration experience & & X & X & \\
Compliance with deadlines set for the project & & X & & \\
Learning spirit of the teams & & X & & \\
Objectivity & & X & & \\
\hline
\end{tabular}

management subsystems alignment with the organisation business plans (Teo \& Ang, 1999), and promotes organisation commitment, enabling the top management to demonstrate their compromise with the strategy (Salaheldin, 2009). According to Teo and Ang (1999), this commitment may even lift the organisation's management status and consequently lead the organisation to a strengthening between the management and several departments.

Management commitment is one of the most important factors at an early stage (Nah, Lau, \& Kuang, 2001), facilitating the necessary human and financial resources allocation to implement and/or integrate management subsystems (Teo \& Ang, 1999). In fact, without these features, the integration process is compromised.

Responsibilities assignment in relevant practices during the integration process had been identified as CSF (Awan, Bjatti, Bukhari, \& Qureshi, 2008). In order to properly assign responsibilities, the authors mentioned that synergies should be promoted between human, financial and marketing resources functional areas and the remaining organisation functional areas.

Training, mainly in areas where scientific and technical progress is constant, is decisive for a system to work perfectly without the occurrence of nonconformities. Quality, environmental and occupational safety and health standards emphasise that training is important to assign the organisation's employees responsibilities, and should be enhanced for their effectiveness assessment. Welikala and Sohal (2008) rated education and training as the most important successful implementation factors. Yusof and Aspinwall (2000) and Salaheldin (2009) also identify the human and financial resources, as well education and training, as CSF of the integration process. Furthermore, Salaheldin (2009) states that these factors have a strong impact on the operational performance.

Employees' motivation and involvement are essential to achieve a management system implementation/integration, to effectively maintain management systems (Cheng \& Tummala, 1998) and to successful continuous improvement efforts (Abdullah, Uli, \& Tarí, 2009). Cheng and Tummala (1998) described employees as managers, supervisors and operators and emphasise that workers attitude and behaviour are crucial to achieve a successful management system implementation/integration and system future maintenance. According to Welikala and Sohal (2008), the lack of employees' involvement and commitment makes them not responsible for the system. They should be made aware that they are part of it. 
Another factor identified as critical to subsystems integration was the existence of consultants with experience concerning the scope of management system integration. In fact, this factor relates to the difficulties experienced by organisations when hiring a consultant who proved to be inexperienced in management systems integration. Again, the training factor is emphasised as critical for successful subsystems integration.

Organisations studied also identified other factors that are considered as secondary:

- Persistence;

- Clearly defined objectives;

- Compliance with deadlines defined in the project;

- Teams learning spirit;

- Objectivity.

Among the strategic factors sustaining a successful implementation and/or management subsystems integration, a clear objectives definition is, according to Salaheldin (2009), one of the most important factors. Harry and Schroeder (2006) and Trad and Maximiano (2009) stress that successful implementation does not happen without an active leadership, with clearly defined objectives that should be communicated to all the employees. Pande, Neuman, and Cavanagh (2000) also point out the importance of projects being based on defined needs and sharp objectives and aligned with the organisation's strategy.

Resources allocated to the system focusing on strategies development and operational performance improvement are important and necessary for meeting the milestones previously established in the project. This factor is critical and can be undermined if the top management is not committed (Teo \& Ang, 1999). The development of a monitoring plan is very important and should be included in the milestones checklist.

Concerning the staff's learning spirit, Salaheldin (2009) states that the higher it is, the greater is the influence on the operational performance and, consequently, more probable is the success of the implementation and/or subsystems integration.

It is also important that organisations become objective in their projects, namely in those related to systems integration.

\section{Conclusions}

The number of Portuguese organisations with an IMS is increasing, both in absolute number and in diversity. Companies are 'starving' for information regarding how to implement a successful IMS.

The adoption of an IMS is, nowadays, an important strategic decision in order to promote higher levels of competitiveness and sustainability. Successful management subsystems integration is significantly related to the true motivation that leads organisations to integrate. To achieve this effectiveness and an 'all-in-one' integration level, organisations need to comply with a set of factors that will lead to a successful integration and to a better system control.

With subsystems integration, and according to the studied organisations, it is possible to identify a set of benefits which reflect the integration motivation. In practical terms, the resultant benefits are related to organisation structural changes, namely concerning processes, documentation, communication and employees responsibilities. Despite the benefits that could be achieved with management system integration, some difficulties have been pointed out, namely those related with organisation culture changes. 
The integration level could be influenced by the implementation sequence and the standards integration. Based on the achieved results, one may conclude that the implementation sequence follows, in most situations, the standards publication sequence. This can be a major factor, to the extent that, usually, organisations implement ISO 14001 and OHSAS 18001 after a pre-existing and entrenched QMS.

There are several CSFs related to management systems integration. Since not all of them have the same importance, based on the literature and on the current study, the most important ones were: top management involvement, human resources suitability and motivation, financial resources availability, appropriate training and external consultants' experience in management subsystems integration.

Results from the current study are highly important for organisations that plan to implement or integrate their management subsystems, because they now have the knowledge regarding the CSF leading to subsystems integration. It is also important that organisations' top management be aware of the potential difficulties they might face during the integration process.

\section{References}

Abdullah, M., Uli, J., \& Tarí, J. (2009). The relationship of performance with soft factors and quality improvement. Total Quality Management \& Business Excellence, 20(7), 735-748.

Abrahamsson, S., Hansson, J., \& Isaksson, R. (2010). Integrated management systems - advantages, problems and possibilities. Visby: Gotland University.

Al-Darrab, I.A., Gulzar, W.A., \& Ali, K.S. (2012). Status of implementation of safety, quality and environmental management systems in Saudi Arabian industries. Total Quality Management and Business Excellence, 24(3), 336-354. doi:10.1080/14783363.2012.733257

Asif, M., Fisscher, O., Bruijn, E., \& Pagell, M. (2010). Integration of management systems: A methodology for operational excellence and strategic flexibility. Operations Management Research, 3, 146-160.

Awan, H., Bjatti, M., Bukhari, K., \& Qureshi, M. (2008). Critical success factors of TQM: Impact on business performance of manufacturing sector in Pakistan. International Journal of Business and Management Science, 1, 197-203.

Beckmerhagen, I., Berg, H., Karapetrovic, S., \& Willborn, W. (2003). Integration of management systems: Focus on safety in the nuclear industry. International Journal of Quality \& Reliability Management, 20(2), 210-228.

Bernardo, M., Casadesus, M., Karapetrovic, S., \& Heras, I. (2009). How integrated are environmental, quality and other standardized management systems? An empirical study. Journal of Cleaner Production, 17, 742-750.

Billig, O., \& Camilato, S. (2008). Sistema de gestão integrada de qualidade, segurança, meio ambiente e saúde. São Leopoldo: Unisinos.

Brio, J., Fernández, E., Junquera, B., \& Camilo, J. (2001). Joint adoption of ISO 14000-ISO 9000 occupational risk prevention practices in Spanish industrial companies: A descriptive study. Total Quality Management \& Business Excellence, 12(6), 669-686.

Capelas, L. (2002). Manual Prático para a Certificação e Gestão da Qualidade com Base nas Normas ISO 9000:2000. Lisboa: Verlag Dashöfer.

Castillo-Rojas, S.M., Casadesús, M., Karapetrovic, S., Coromina, L., Heras, I., \& Martín, I. (2012). Is implementing multiple management system standards a hindrance to innovation? Total Quality Management and Business Excellence, 23(9-10), 1075-1088.

Cheng, S., \& Tummala, V. (1998). An employee involvement strategy for ISO 9000 registration and maintenance: A case study for Hong Kong and China companies. The International Journal of Quality \& Reliability Management, 15(8/9), 860-891.

Crowder, M. (2013). Quality standards: Integration within a bereavement environment. The TQM Journal, 25(1), 18-28.

Domingues, J.P.T., Sampaio, P., \& Arezes, P.M. (2012). New organizational issues and macroergonomics: Integrating management systems. International Journal of Human Factors and Ergonomics, 1(4), 351-375. 
Douglas, A., \& Glen, D. (2000). Integrated management systems in small and medium enterprises. Total Quality Management \& Business Excellence, 11(4/5\&6), S686-S690.

Eisenhardt, K. (1989). Building theories from case study research. The Academy of Management Review, 14(4), 532-550.

Ferreira, M. (2009). Capacidade de inovação empresarial e políticas públicas de incentivos. Aveiro: Universidade de Aveiro.

Fresner, J., \& Engelhardt, G. (2004). Experiences with integrated management systems for two small companies in Austria. Journal of Cleaner Production, 12, 623-631.

Garengo, P., \& Biazzo, S. (2012). From ISO quality standards to an integrated management system: An implementation process in SME. Total Quality Management and Business Excellence, 24(3), 310-335. doi:10.1080/14783363.2012.704282

Gill, J. (2009). Quality follows quality: Add quality to the business and quality. The TQM Journal, 21(5), 530-539.

Grael, P., \& Oliveira, O. (2009). Sistemas certificáveis de gestão ambiental e da qualidade: Práticas para integração em empresas do sector moveleiro. Produção, 10(1), 30-41.

Harry, M., \& Schroeder, R. (2006). Six sigma: The breakthrough management strategy revolutionizing the world's top corporations. New York, NY: Doubleday.

Hoyle, D. (2005). ISO 9000 quality systems handbook (5th ed.). Oxford: Elsevirer ButterworthHeinemann.

Hypolito, C., \& Pamplona, E. (1999). Sistemas de gestão integrada: Conceitos e principais considerações em uma implantação. XIX Encontro Nacional de Engenharia de Produção, Rio de Janeiro.

ISO. (2010). FAQs on ISO 9001:2008. International Organization for Standardization. Retrieved June 2011, from http://www.iso.org/iso/iso_catalogue/management_standards/quality_management/ iso_9001_2008/faqs_on_iso_9001.htm

Kanji, G., \& Chopra, P. (2010). Corporate social responsibility in a global economy. Total Quality Management \& Business Excellence, 21(2), 119-143.

Karapetrovic, S. (2002). Strategies for the integration of management system and standards. The TQM Magazine, 14(1), 61-67.

Karapetrovic, S., \& Casadesús, M. (2009). Implementing environmental with other standardized management systems: Scope, sequence, time and integration. Journal of Cleaner Production, 17, $533-540$.

Karapetrovic, S., \& Jonker, J. (2003). Integration of standardized management systems: Searching for a recipe and ingredients. Total Quality Management \& Business Excellence, 14(4), 451-459.

Kuei, C.-h., \& Lu, M.H. (2013). Integrating quality management principles into sustainability management. Total Quality Management and Business Excellence, 24(1-2), 62-78.

Meredith, J. (1998). Building operations management theory through case and filed research. Journal of Operations Management, 16, 441-454.

Miguel, P., \& Dias, J. (2009). A proposed framework for combining ISO 9001 quality system and quality function deployment. The TQM Journal, 21(6), 589-606.

Mitchison, N., \& Papadakis, G.A. (1999). Safety management systems under Seveso II: Implementation and assessment. Journal of Loss Prevention in the Process Industries, 12, $43-51$.

Nah, F., Lau, J., \& Kuang, J. (2001). Critical factors for successful implementation of enterprise systems. Business Process Management Journal, 7(3), 285-296.

Pande, P., Neuman, R., \& Cavanagh, R. (2000). The six sigma way: How GE, Motorola, and other top companies are honing their performance. New York, NY: McGraw-Hill.

Patrício, C. (2003). Integração dos sistemas de gestão. XIII Jornadas Hispano-Lusas de Gestión Científica, Santiago de Compostela, 113-118.

Pinto, A. (2005). Sistemas de gestão da segurança e saúde no trabalho - Guia para a sua implementação (1st ed.). Edições Sílabo, Lisboa.

Pojasek, R. (2007). A framework for business sustainability. Environmental Quality Management, $17(2), 81-88$.

Rasmussen, J., \& Jørgensen, T. (2007). Integrated management systems: An analysis of best practice in Danish companies. Aalborg: Aalborg University.

Renzi, M., \& Cappelli, L. (2000). Integration between ISO 9000 and ISO 14000: Opportunities and limits. Total Quality Management \& Business Excellence, 11(4/5\&6), S849-S856. 
Salaheldin, S. (2009). Critical success factors for TQM implementation and their impact on performance of SMEs. International Journal of Productivity and Performance Management, 58(3), 215-237.

Sampaio, P., \& Saraiva, P. (2010a). Integração ou adição de sistemas de gestão? Revista Qualidade, Primavera-Verão, 36-40.

Sampaio, P., \& Saraiva, P. (2010b). Integration of quality, environmental, occupational health and safety management systems. CESET Journal, 1(7), 16-27.

Sampaio, P., Saraiva, P., \& Domingues, P. (2012). Management systems: Integration or addition? International Journal of Quality and Reliability Management, 29(4), 402-424.

Sampaio, P., Saraiva, P., \& Rodrigues, A. (2008). Sistemas de gestão: Da qualidade para outros sistemas. International Symposium on Occupational Safety and Hygiene, Guimarães.

Santos, G., Mendes, F., \& Barbosa, J. (2011). Certification and integration of management systems the experience of Portuguese small and medium enterprises. Journal of Cleaner Production, 19(17-18), 1965-1974.

Simon, A., Bernardo, M., Karapetrovic, S., \& Casadesús, M. (2012). Implementing integrated management systems in chemical firms. Total Quality Management and Business Excellence, 24(3), 294-309. doi:10.1080/14783363.2012.669560

Teo, T., \& Ang, J. (1999). Critical success factors in the alignment of IS plans with business plans. International Journal of Information Management, 19, 173-185.

Trad, S., \& Maximiano, A. (2009). Seis Sigma: Fatores críticos de sucesso para sua implantação. Revista de Administração Contemporânea, 13(4), 647-662.

Vasconcelos, D., Melo, M., \& Silva, L. (2010). PAS 99:2006 as an integrated management system the study of a case. CESET Journal, 1(7), 79-89.

Voss, C., Tsikriktsis, N., \& Frohlich, M. (2002). Case research in operations management. International Journal of Operations \& Production Management, 22(2), 195-219.

Waclawovsky, E., \& Batiz, E. (2010). Proposta de metodologia para implementação de sistemas de gestão integrados como ferramenta de apoio no alcance de resultados sustentáveis para as organizações. XIII Simpósio de Administração da Produção, Logística e Operações Internacionais, São Paulo.

Welikala, D., \& Sohal, A. (2008). Total quality management and employees' involvement: A case study of an Australian organisation. Total Quality Management \& Business Excellence, 19(6), 627-642.

Yusof, S., \& Aspinwall, E. (2000). Critical success factors in small and medium enterprises: Survey results. Total Quality Management, 11(4), 448-462.

Zeng, S.X., Xie, X.M., Tam, C.M., \& Shen, L.Y. (2011). An empirical examination of benefits from implementing integrated management systems (IMS). Total Quality Management and Business Excellence, 22(2), 173-186. 